\title{
EFFECT OF INVESTOR SENTIMENT ON STOCK MARKETS
}

\author{
Özge BOLAMAN* \\ Pinar EVRIM MANDACI**
}

\begin{abstract}
Motivation of this study is to examine the relationship between investor sentiment and stock market by taking financial crisis period into account. When literature is examined, it is seen that there is a deficiency in this respect. Although there are studies examining same phenomena, none of them has considered the impact of financial crisis. To eliminate this deficiency, we have employed tests with structural breaks rather than conventional ones. At the end of these tests, structural breaks are observed at crisis period as it is expected. By employing data for the period December 2003- December 2012 existence of co-integration, which is an indicator of a long-term relationship between variables, is proved. This is a significant insight showing that consumer confidence index is a critical factor which is in an interaction with stock markets.
\end{abstract}

Keywords: Stock Markets, Investor Sentiment, Consumer Confidence Index, Financial Crisis, Cointegration

Jel Codes: D53, G01, G02

\section{YATIRIMCI DUYARLILIĞININ HİSSE SENEDİ PİYASALARINA ETKİSI}

\section{Öz}

$\mathrm{Bu}$ çalışma finansal kriz döneminin etkisini de göz önünde bulundurarak yatırımcı duyarlılığı ile borsa arasındaki ilişkiyi araştırma amacıyla hazırlanmıştır. Akademik literatür incelendiğinde bu alanda bir eksiklik görülmüştür. Aynı konuyu araştıran birçok makale olmasına rağmen, hiçbiri finansal krizlerin etkisini hesaba katmamıştır. Bu eksikliği gidermek adına bu çalışmada standart testler yerine yapısal kırılmalı testler kullanılmıştır. Testlerin sonucunda beklentiye paralel olarak kriz döneminde yapısal kırılmalar

\footnotetext{
* Arş.Gör.,Pamukkale Üniversitesi,Uluslararası Ticaret ve Finansman Bölümü, obolaman@pau.edu.tr

** Prof.Dr., Dokuz Eylül Üniversitesi, İngilizce İşletme Bölümü, pinar.evrim@deu.edu.tr
} 
tespit edilmiştir. Aralık 2003-Aralık 2012 verisi kullanılarak yapılan analizlerde değişkenler arasında uzun dönemli ilişkinin varlığını gösteren eşbütünleşmenin varlığı kanıtlanmıştır. Buda borsalarla etkileşim içinde olan tüketici güven endeksinin kritik bir faktör olduğu gösteren bir bulgudur.

Anahtar Kelimeler: Hisse Senedi Piyasaları, Yatırımcı Duyarlılığı, Tüketici Güven Endeksi, Finansal Kriz, Eşbütünleşme

Jel Kodları: D53, G01, G02

\section{Introduction}

There are many studies supporting not only the relationship between stock returns and economic indicators like interest rates, GDP growth rates, inflation rate; but also the relationship between consumer sentiment and economic indicators. (see Weder, 1998; Howrey, 2001; Bremmer, 2008; Chen, 2011 and i.e) Here it is logical to expect a relationship between stock returns and consumer sentiment. By assuming that consumer confidence index is a proxy for investor sentiment, existence of such a relationship will be investigated during this study.

Traditional finance theory states that stock prices reflect discounted value of expected cash flows and irrationalities in the market is eliminated by arbitrageurs. It does not take theory of sentiment into account. However traditional finance theory remains insufficient in explanation of stock market returns. Here behavioral approach comes into place which states that irrational sentiment of investors may affect markets for a significant time period and arbitrage is risky and limited. Consistently, Schleifer (2003) notes that stock prices could be estimated when investor sentiment is taken into account with limited arbitrage.

Beginning from the seminal paper of Delong et al. (1990) which defines sentiment as the component of expectations about asset returns that are not warranted by fundamentals, many papers examining how to measure investor sentiment are written. Since investor sentiment is hard to measure, there is a great variability in what variables used to proxy for it. There are lots of papers which proxy investor sentiment with consumer confidence. (Ho and Hung (2009), Schmeling (2009), Akhtar et al. (2011), Zouaoui et al (2011)). According to Fisher and Statman (2002), although investor sentiment and consumer sentiment are not the same things, there is a positive and significant relationship between them. They have reported positive correlations between measures of consumer confidence and a direct measure of investor sentiment compiled by American Association of individual investors over the period 1987-2000. Since then using this metric as a measure of investor sentiment becomes natural. Moreover due to fact that consumer confidence is surveyed in most countries, it is the only consistent way to obtain a sentiment proxy which gives opportunity to make comparison across countries. From the perspective of Turkey, there is not a direct index which measures investor sentiment directly. This deficiency requires making an assumption in examination of the relationship between investor sentiment and stock market. In this paper, we try to examine the relationship between the Turkish stock market and 
investor sentiment by using CCI that has been released by the Central Bank of Turkey since December 2003.

Examining the relationship between the stock market returns and investor sentiment is essential for the investors and portfolio managers to find out whether they can use CCI as a predictor of future stock returns. If this is the case, it will be possible to use CCIs for shortterm market timing. Two reasons might be proposed to establish a relationship between stock prices and consumer confidence index (as a proxy for investor sentiment). The first reason can be explained by the link between consumer spending and corporate profits. If the consumer confidence decreases, the consumer spending will also decrease which in turn will cause a decrease in corporate profits and stock prices. The second reason can be explained by the publication effect indicating that the publication of the CCIs might cause a psychological effect on the market prices. Although many researches consequently expect that the changes in consumer confidence will impact the stock returns, most of them find an opposite relationship indicating that the stock price movements affect the consumer confidence. These researchers suggest two reasons for their results. The first can be explained by the traditional wealth effect demonstrating that the stock prices affect the current wealth of the investors which in turn affects their confidence. Wealth effect only applies to consumers with direct investments in stock exchange. This direct effect is said to be less important for Turkey like continental Europe where few households invest in stocks with a smaller share of wealth compared to USA. Second reason can be explained by the leading indicator channel denoting that the current changes in stock prices will affect future incomes and consumer confidence. This explanation is made by Otoo (1999) following Poterba and Samwick (1995), Morck, Shleifer and Vishny (1990). Here higher stock prices are interpreted as a sign of favorable future economic conditions. This channel influences behavior of all consumers independent from the stake they own in stock market. From another perspective, poor stock returns may be associated with possible job-cutoffs and restructuring by consumers. With the fall of stock market, consumer confidence decreases due to concerns about job security and future income.

In this paper, we try to examine the relationship between the BIST 100 index and CCI (as a proxy of investor sentiment) of Turkey by using monthly data from December 2003 to December 2012. We implement Ziwot Andrews and Gregory Hansen tests to find out whether a relationship exists between stock market and consumer confidence index. The paper has three important contributions to the finance literature. First, while most of the previous studies examine the relationship between the investor sentiment and stock market for the developed countries, only a few studies have examined this relationship for the emerging markets including Turkey which usually provides greater opportunities than the developed markets to both domestic and international investors. Second, our data period covers a longer term than those of the previous studies for Turkey. Additionally it is the first study that also covers period of latest ruinous global financial crises. Considering the crises period in analysis is important since the main reason that encourages the researchers to study the relationship between the consumer confidence and stock market is to find out whether this relationship is stronger during this period. 
The rest of the paper is organized as follows. Section 2 provides a brief literature review. Section 3 gives methodology. Section 4 presents our data and empirical results, and Section 5 concludes the paper.

\section{Literature Review}

The study of Otoo (1999) is the first examining the relationship between equity prices and consumer confidence by using monthly data of Wilshire 5000 stock index from June 1980 to June 1999. His Granger causality test results indicate that stock price movements affect changes in consumer confidence but the lagged changes in confidence have no explanatory power for stock prices. Movements in equity prices can be used as a leading indicator. In their studies Jansen and Nahuis (2003), Brown and Cliff (2004), and Bremmer (2008) support the findings of Otoo (1999) demonstrating that the current stock prices predict future consumer confidence.

Among these studies, Jansen and Nahuis (2003) extend the study of Otoo (1999) by examining eleven European countries for the period from 1986 to 2001. They find positive relationship between the changes in stock prices and consumer confidence for nine countries and argue that stock returns and consumer confidence are correlated in countries where stock ownership is high such as U.K. They find that the stock returns impact consumer confidence at very short horizons (2 weeks-1 month). In their study, Brown and Cliff (2004) use monthly data from March 1965 and December 1998 and weekly data from July 24, 1987 through December 18, 1998 for the U.S Stock market. Their results are similar to the results of Otoo (1999) and Jansen and Nahuis (2003) indicating a perfect positive relationship between the market returns and consumer sentiment. Their VAR analysis reveals that market returns predict future sentiment however little evidence suggests that sentiment predicts market returns. They group the investors' sentiment as individual and institutional investors' sentiment. After then they argue that institutional sentiment may primarily affect large stocks, whereas individual investors' sentiment may affect small stocks. This is the case since large part of the market for large stocks is formed by institutional investors.

Different from the previous studies Bremmer (2008) examine the relationship between the consumer confidence and the most common stock indices such as Dow Jones, S\&P 500 and NASDAQ and applies co-integration tests to measure the long-run relationship. However he does not observe a long run relationship between the consumer confidence and these stock indices. Additionally, he argue that while expected changes in consumer confidence have no impact on stock prices, unexpected changes are related to changes in stock prices.

Spyrou (2012) examine the relationship between the monthly returns of US stock portfolios that are formed on book-to-market equity (B/M), long term reversals, momentum, and size, a for the period from 1965 to 2007 and finds that contemporaneous returns are significantly related to monthly sentiment changes and tend to be higher during periods of negative sentiment. Stock returns, however, are more important in predicting sentiment changes than vice versa. In 
addition, he finds that the conditional return volatility is significantly affected by lagged volatility rather than sentiment changes.

In contrast to these studies there are a few arguing that the consumer confidence predicts stock returns. Among these studies, Fisher and Statman (2003) examine the relationship between the consumer confidence that is measured by both the Michigan's CCI and Conference Board CCI and S\&P 500, NASDAQ and small cap stock returns. Their results indicate that the consumer confidence predicts the stock return and they find a negative relationship between consumer confidence level and future stock returns. In contrast, they find a positive relationship for high stock returns indicating that the high returns boost the consumer confidence. When they consider the investors as individual and institutional, they find a statistically significant relationship between changes in consumer confidence and changes in the sentiment of individual investors. However they do not observe a significant relationship between changes in consumer confidence and changes in sentiment of Wall Street strategists.

Baker and Wurgler (2007) find that both global and local sentiment predicts the market returns as well as relative returns for the small, highly volatile, distressed and growth portfolios for six major stock markets. Similarly by using CCI as a proxy for investor sentiment Schmeling (2009) examine the relationship between investor sentiment and future stock returns for 18 industrialized countries for the period from January 1985 to December 2005 and find that the sentiment negatively forecasts expected returns on average across countries. This relation also holds for returns of value stocks, growth stocks, small stocks, and for different forecasting horizons. Moreover they find that the impact of sentiment on returns is stronger for countries that have less well developed market institutions and for countries that are culturally more prone to investor overreaction.

Chen (2011) is the first study that examines the asymmetric effects of negative sentiment during market fluctuations. Parallel to the Prospect Theory when market is not performing well, investor sentiment is expected to have larger impact on stock prices in bear markets. He uses monthly returns of S\&P 500 Price index from 1978 to 2009 by using Markov-Regime switching model and the results support the asymmetric effect and reveal that the impact is greater in bear market. Additionally he finds that the greater the market pessimism, the higher is the probability of switching from a bull to a bear market.

There are only a few studies examining the relationship between the consumer sentiment and Turkish stock market. Among them, Canbaş and Kandır (2007) use the regression analysis to examine the relationship between the investor sentiment and sector indices of Turkish stock market. They use different variables to measure investor sentiment for the period from July 1997 to June 2006 and conclude that the sector indices are affected by all measures investor sentiment. Korkmaz and Çevik (2009) investigate dynamic causality between confidence index and stock market return by using data of 1987-2008. They find a feedback relationship between variables and state that variables affect each other simultaneously. And lastly Topuz (2011) finds a unidirectional causality from stock prices to CCI by using data of CCI and ISE-100 index. 


\section{Methodology}

Firstly we implement the ADF (1981) test to determine whether the variables are stationary or not. After then Ziwot Andrews test which enables us to show the impact of financial crises is implemented.

Next step is the implementation of co-integration test to examine if a long-run relationship between variables exists. Here Gregory Hansen co-integration test that allows for a possible structural break will be benefited.

\section{Data and Empirical Results}

We use monthly data for the period from December 2003 to December 2012. We collect CCI from the web page of Central Bank of Turkey and BIST100 index from the web page of Borsa Istanbul. Table 1 depicts the descriptive statistics of our variables.

Table I. Descriptive Statistics

\begin{tabular}{|c|c|c|}
\hline & CCI & Log of BIST100 \\
\hline Mean & 91.68519 & 0.015700 \\
\hline Median & 92.10000 & 0.018314 \\
\hline Maximum & 111.9000 & 0.177874 \\
\hline Minimum & 68.90000 & -0.276878 \\
\hline Std. Dev. & 9.488525 & 0.071581 \\
\hline Skewness & -0.194788 & -0.635530 \\
\hline Kurtosis & 2.770623 & 4.803018 \\
\hline Jarque Bera & 0.919724 & 21.89912 \\
\hline Probability & 0.631371 & 0.000018 \\
\hline
\end{tabular}

According to Table 1, results from Jarque-Bera test statistics testing null hypothesis of no deviations from normality indicate that while the null hypothesis could not be rejected for CCI, it is rejected for BIST100 index at $5 \%$ significance level. In other words CCI is said to have normal distribution. On the other hand the logarithmic series of BIST100 index is not normally distributed.

Skewness of a normal distribution is zero. Negative skewness values indicate the data which is skewed to left. This means that left tail is longer relative to right tail. According to Brooks (2008) kurtosis of normal distribution is 3. With same reference positive kurtosis indicates a "peaked" distribution, whereas negative kurtosis indicates a "flat" distribution. Since both of our variables have positive kurtosis values, we could say that they have a "peaked" distribution. 
Table 2 gives the results of ADF test. Our results indicate that the null hypothesis of existence of unit root cannot be rejected at level of CCI series at 5\% level, and the null hypothesis of unit root is rejected at first difference of the same series at 5\% level. On the other hand, the null hypothesis of unit root is rejected at level of the log of BIST 100 index.

Table 2. ADF Test Results

\begin{tabular}{|l|c|c|}
\hline & Level & First Difference \\
\hline \multirow{3}{*}{ CCI } & $\eta_{\mu}-2.338699$ & $-8.016905^{\star}$ \\
$(12)$ & $(12)$ \\
& {$[-2.888669]$} & {$[-2.888669]$} \\
\hline & $\eta_{\tau}-2.130895$ & $-8.076262^{\star}$ \\
$(12)$ & $(12)$ \\
& {$[-3.452358]$} & {$[-3.452358]$} \\
\hline \multirow{3}{*}{ Log of BIST 100 } & $\eta_{\mu-7.847431^{\star}}(12)$ & \\
& {$[-2.888669]$} & - \\
\hline & $\eta_{\tau}-4.498680^{*}$ & \\
& $(12)$ & - \\
& {$[-3.453170]$} & \\
\hline
\end{tabular}

$\eta_{\tau}$ and $\eta_{\mu}$ refer to the test statistics with and without trend, respectively. ${ }^{\star}$ and ${ }^{*}$ denote rejection of null hypothesis at $1 \%$ and $5 \%$, respectively. Numbers in parenthesis are optimum lags determined according to the Akaike Information Criteria (AIC) Numbers in brackets are Mckinnon critical values for $\% 5$

Most frequently mentioned problem with conventional unit root tests like ADF is that they do not allow for the possibility of a structural break. Ziwot Andrews (1992) has formed a testing procedure where time of the break is estimated rather than assumed as an exogenous phenomenon. Ziwot Andrews test has developed three models for testing unit root. They are Model A which permits a one-time change in the level of series, Model B which allows for a one-time change in the slope of the trend function and finally Model $\mathrm{C}$ that combines one-time changes in the level and slope of the trend function of the series. Empirical investigation of the model will be based on model $\mathrm{C}$, since it is the least restrictive of three model of ZA.

Table 3. Ziwot Andrews Unit Root Test

\begin{tabular}{|l|c|c|}
\hline Variable & Break Date & Min t-stat \\
\hline CCI & $2008 \mathrm{~m} 02$ & $\begin{array}{c}-4.986900 \\
{[-5.08]}\end{array}$ \\
\hline Log of BIST-100 Index & $2008 \mathrm{~m} 01$ & $\begin{array}{c}-3.432437 \\
{[-5.08]}\end{array}$ \\
\hline
\end{tabular}

* Numbers in brackets are the critical values 
From table 3 it is seen that both variables have unit roots with structural break. In other words null hypothesis asserting that series have unit roots with structural break is accepted since ZA t-statistics of both variables are smaller than critical values in absolute term. When ADF test is implemented however, only CCI has found as having unit root. Break date for BIST-100 index is found as January-2008 which is not a surprising result. Although global crisis has begun in August 2007 in USA, stock market has risen in Turkey until December 2007. With the effect of global crisis, BIST has started to fall beginning from January-2008. BIST-100 index which is 55.538,13 in Dec-2007 has fallen into 44.304,44 in Jan-2008. Fast falling period of CCI begin with Feb-2008 which is the break date for CCI. These days are the ones when the entire world worries about American economy. Fall of BIST-100 index also creates a fear in our country since it is associated with economic crisis. As a result of this case, CCI has fallen sharply in Feb-2008. Structural breaks could be seen on figure 1 .

For

INDEX For

CCI
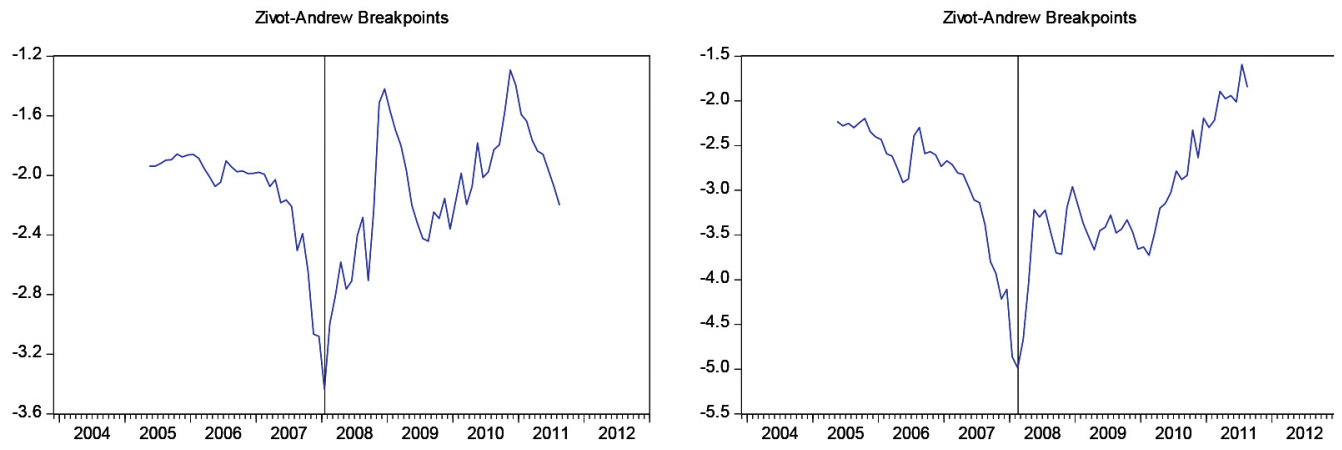

Figure. I

Following completion of unit root testing, next step is the estimation of the VAR model. Before estimation of VAR model, appropriate lag number is determined according to AIC information criteria. After then stability and normality conditions, autocorrelation and heteroscedasticity are tested.

Table 4. Testing of Stability, autocorrelation and heteroscedasticity

Lag Number Stability Normality Autocorrelation Heteroscedasticity

1 exist exist not exist not exist


As all conditions are met, co-integration relationship between variables could be examined. Co-integration is investigated in order to examine existence of a long-term relationship between variables both of which have unit root with structural breaks. Co-integration will be investigated by Gregory Hansen methodology in which single break date is determined endogenously. Gregory and Hansen (1996) have tested null hypothesis of no co-integration according to critical values which they obtain by modifying Mackinnon (1991) procedure. In the examination of co-integration relationship, by following Murray (1994) level values of variables are used. Murray (1994) has defined using first difference variables as a mistaken way for looking linear relationships between potentially integrated variables.

Table 5. Results of Gregory Hansen Co-integration Test

\begin{tabular}{|c|c|c|c|c|}
\hline Model & Test stat. & Break date & Critical Value (\%5) & Critical Value (\%1) \\
\hline C & -8.209567 & $2009 \mathrm{~m} 01$ & -4.61 & -5.13 \\
\hline $\mathbf{C} / \mathbf{T}$ & -8.495954 & $2009 \mathrm{~m} 03$ & -4.99 & -5.45 \\
\hline $\mathbf{C} / \mathbf{S}$ & -8.646657 & $2008 \mathrm{~m} 11$ & -4.95 & -5.47 \\
\hline
\end{tabular}

* Critical values are taken from Gregory Hansen (1996)

Based on table 5, null hypothesis asserting there is no co-integration between variables is rejected since min calculated ADF test statistic is larger than critical values of Gregory Hansen in absolute terms. In other words, a long-term relationship between variables is found. Moreover structural breaks exist for three models.

\section{Conclusion}

Examining the relationship between the investor sentiment and stock market has become an important issue among the finance researchers mostly studying on the market efficiency and behavioral finance. While early studies use various types of measures of investor sentiment, most of the current studies use CCIs which are generated through surveys as proxies for investor sentiment. This paper tries to investigate the relationship between the logarithm of BIST-100 Index and CCI released by Central Bank of Turkey for the period from December 2003 to December 2012 covering the recent financial turmoil.

Our paper contributes to the literature in three ways: First, while the existing literature mostly focuses on the developed markets, we examine the Turkish stock market that is one of the most important emerging markets offering high returns. Second, our data period is longer than those of the other studies for Turkish stock market and it covers the latest financial crisis that enable us to examine the relationship between the consumer confidence and stock market during the crises period. At the end of the study structural breaks for both variables are observed in the 
period of crises which is in consistence with expectation. Existence of co-integration has proved us existence of a long term relationship between variables. Moreover by finding co-integration relationship between variables, functional identity of consumer confidence is revealed. It's proved that consumer confidence which could be an alternative proxy for investor sentiment is also needed to be followed since it is a critical factor for prospect of the financial markets. 


\section{References}

AKHTAR, Shumi , Faff, Robert., OLIVER, Barry and SUBRAHMANYAM, Avanidhar (2011) “The power of bad: The negativity bias in Australian consumer sentiment announcements on stock returns" Journal of Banking and Finance, Vol.35,pp.1239-1249.

ASTERIOU, Dimitrios and HALL, G. Stephen (2007) Applied Econometrics, Palgrave Macmillan.

BAKER, Malcolm and WURGLER, Jeffrey (2007) "Investor Sentiment in the Stock Market" Journal of Economic Perspectives, Vol.21, issue 2, pp. 129-152.

BOLLERSLEV, Tim (1986) “Generalized Autoregressive Conditional Heteroscedasticity" Journal of Econometrics, Vol. 31, pp. 307-327.

BREMMER, Dale (2008) "Consumer Confidence and Stock Prices" 72nd Annual Meeting of the Midwest Economics Association Hyatt Regency, Chicago, Illinois, www.rose-hulman.edu/ bremmer/ professional/bremmer_midwest2008.pdf.

BROOKS, Chris (2008), Introductory Econometrics for Finance, 2nd Edition Chris Brooks, ICMA.

BROWN, W. Gregory and CLIFF, T. Michael (2004) "Investor Sentiment and the Near-Term Stock Market" Journal of Empirical Finance, Vol.11,pp.1-27.

CANBAŞ, Serpil and KANDIR, S.Yılmaz (2006) "Yatırımcı Duyarlılı̆̆ının İMKB Sektör Gelirleri Üzerindeki Etkisi”, Dokuz Eylül Üniversitesi İktisadi ve İdari Bilimler Fakültesi Dergisi,Cilt.22, sayı 2, ss.219248.

CHEN, Nai-fu., KAN, Raymond and MILLER, H. Merton (1993) "Are the Discounts on Closed-end Funds A Sentiment Index?” Journal of Finance, Vol.48, issue 2, pp. 795-800.

DELONG, J. Bradford, SHLEIFER, Andrei, SUMMERS, H Lawrence. and WALDMANN, J.Robert (1990) "Noise trader risk in financial markets" Journal of Political Economy, Vol. 98, pp.703-738.

DICKEY, D.A. and FULLER, W.A. (1979) "Distribution of the Estimators for Autoregressive Time Series with a Unit Root" Journal of the American Statistical Association, Vol. 74, pp. 427-431.

ENGLE, Robert (1982) "Autoregressive Conditional Heteroscedasticity with Estimates of the Variance of UK Inflation” Econometrica, Vol.50, pp.987-1008.

EUN, S. Cheol and SIM, Sangdal (1989) “International Transmission of Stock Market Movements” Journal of Financial and Quantitative Analysis, Vol.24, pp. 241-256

FISHER, Kenneth and STATMAN, Meir (2002) “Consumer Confidence and Stock Returns” Working paper, Santa Clara University.

FISHER, Kenneth. and STATMAN, Meir (2003) “Consumer Confidence and Stock Returns" Journal of Portfolio Management, Vol.30, pp. 115-128.

GRANGER, C.W.J. (1969) Investigating Causal Relations by Econometric Methods and Cross-Spectral Methods, Econometrica, Vol.37, issue 3, pp. 424-438.

GREGORY, W.Allan and HANSEN, E. Bruce (1996)"Residual-Based Tests for cointegration in models with regime shifts", Journal of Econometrics, Vol.70, pp.99-126.

HOWREY, E. Philip (2001) “The Predictive Power of the Index of Consumer Sentiment” Brookings Paper on Economic Activity, Vol. 32, issue 1, pp. 175-216.

JANSEN ,W.Jos and NAHUIS, J. Niek (2003) “The Stock Market and Consumer Confidence: European Evidence" Economics Letters, Vol.79, pp. 89-98.

KALOTAY, Egon, GRAY, Philip and SIN, Samantha (2009) "Consumer expectations and short-horizon return predictability” Journal of Banking and Finance,Vol.31,pp. 3102-3124. 
KORKMAZ, Turhan and ÇEVİK, E.İsmail (2009) "Reel Kesim Güven Endeksi ile İMKB 100 Endeksi arasındaki dinamik nedensellik ilişkisi” İstanbul Üniversitesi İşletme Fakültesi Dergisi, Vol. 38, issue 1,pp. 24-37.

MORCK, Randall, SCHLEIFER, Andrei and VISHNY,Robert (1990) “The Stock Market and Investment: Is the market a Sideshow?", Brookings Papers on Economic Activity,Vol.2, pp. 157-202.

MURRAY, P. Michael (1994) “A Drunk and Her Dog: An Illustration of Cointegration and Error Correction." The American Statistician, Vol.48, issue 1, pp. 37-39.

OTOO, M. Ward (1999) “Consumer Sentiment and the Stock Market”, Board of Governors of the Federal Reserve System, http://www.federalreserve.gov/pubs/feds/1999/199960/199960pap.pdf .

POTERBA, James and SAMWICK, Andrew (1995) "Stock Ownership Patterns, Stock Market Fluctuations and consumption" Brookings Papers on Economic Activity, Vol. 2, pp.295-357.

SHLEIFER, Andrei (2003), Inefficient Markets: An Introduction to Behavioral Finance, New York: Oxford University Press.

SCHMELING, Maik (2009) “Investor Sentiment and Stock Returns: Some International Evidence” Journal of Empirical Finance, Vol.16,issue 3, pp. 394-408.

SIMS, A. Christopher (1980) "Macroeconomics and Reality" Econometrica, Vol. 48, issue 1,pp. 1-48.

SPYROU, Spyros (2012) "Sentiment Changes, Stock Returns and Volatility: Evidence from NYSE, AMEX and NASDAQ Stocks” Applied Financial Economics, Vol.22, issue 19, pp.1631-1646.

TOPUZ, Y. Volkan (2011), “ Tüketici Güveni ve Hisse Senedi Fiyatları Arasındaki Nedensellik İlişkisi: Türkiye Örneği” Ekonomik ve Sosyal Araştırmalar Dergisi, Vol.7, issue 1, pp. 53-65.

WEDER, Mark (1998), "Fickle Consumers, Durable Goods, and Business Cycles" Journal of Economic Theory, Vol.81, issue 1,pp. 37-57.

ZIVOT, Eric and ANDREWS, W.K. Donald (1992), "Further Evidence on the Great Crash, the Oil-Price Shock, and the Unit-Root Hypothesis" Journal of Business\&Economic Statistics, Vol.3,pp. 251270.

ZOUAOUI, Mohamed, NOUYRIGAT, Genevieve and BEER, Francisca (2011) "How does investor sentiment affect stock market crises? Evidence from panel data” The Financial Review,Vol.46, pp. 723-747. 


\section{APPENDIX:}

\section{Check for Stability Condition}

\begin{tabular}{|l|l|}
\hline Root & Modulus \\
\hline 0.305684 & 0.305684 \\
\hline 0.088874 & 0.088874 \\
\hline No root lies outside unit circle & \\
\hline Var satisfies stability condition & \\
\hline
\end{tabular}

\section{Check for Autocorrelation}

\begin{tabular}{|l|l|l|}
\hline Lag & LM Stat & Probability \\
\hline 1 & 1.224224 & 0.8741 \\
\hline 2 & 2.122802 & 0.7132 \\
\hline 3 & 3.052033 & 0.5492 \\
\hline 4 & 3.876042 & 0.4230 \\
\hline 5 & 1.372401 & 0.8490 \\
\hline 6 & 9.375432 & 0.0516 \\
\hline 7 & 9.101326 & 0.0586 \\
\hline 8 & 5.996754 & 0.1994 \\
\hline 9 & 1.220499 & 0.8747 \\
\hline 10 & 4.504730 & 0.3420 \\
\hline 11 & 1.017577 & 0.9071 \\
\hline 12 & 7.265026 & 0.1225 \\
\hline
\end{tabular}

At the $5 \%$ significance level, no autocorrelation seems.

\section{Check for Heteroscedasticity}

\begin{tabular}{|c|c|c|}
\hline Chi-square & Degrees of Freedom & Probability \\
\hline 24.98439 & 15 & 0.0502 \\
\hline
\end{tabular}

At $5 \%$ significance level heteroskedasticity does not exist 


\section{Check for Normality}

\begin{tabular}{|c|c|c|c|}
\hline Component & Jarque-Bera & df & Probability \\
\hline 1 & 2.424678 & 2 & 0.2975 \\
\hline 2 & 1.678538 & 2 & 0.4320 \\
\hline Joint & 4.103216 & 4 & 0.3922 \\
\hline
\end{tabular}

At $5 \%$ significance level residuals are normal 